J. Clin. Chem. Clin. Biochem.

Vol. 25, 1987, pp. 919-932

(C) 1987 Waiter de Gruyter \& Co.

Berlin - New York

\title{
A Multicentre Evaluation of the Boehringer Mannheim/Hitachi 704 Analysis System
}

\author{
By P. M. Bayer
}

Wilhelminen-Spital, Vienna

M. Knedel

Klinikum Großhadern, Munich

N. Montalbetti, S. Brenna, L. Prencipe

Ospedale Niguarda-Ca'Granda, Milan

A. Vassault, M. Bailly, H. T. Phung

Hôpital Necker, Paris

in collaboration with

W. Bablok, W. Poppe and W. Stockmann

Boehringer Mannheim GmbH, Mannheim

(Received August 17, 1987)

Summary: The selective multitest Boehringer Mannheim/Hitachi 704 analysis system was examined according to the ECCLS guidelines in a multicentre evaluation involving four laboratories. Ten routine parameters, covering most of the application settings of the instrument, were measured in the respective laboratory at temperatures 25,30 or $37^{\circ} \mathrm{C}$. The trial lasted four months and gave more than 40000 data. It yielded the following results:

1. Within the four laboratories the mean coefficients of variation for three control sera at different concentrations were found to be equal to or better than $1.6 \%$ for the within-run imprecision and $2.8 \%$ or better for the between-day imprecision.

2. No drift was observed during eight hours.

3. Because of the high linear measuring range a re-run analysis was seldom necessary.

4. Sample-related carry-over was not seen. Reagent-dependent carry-over was measured from cholesterol to uric acid and from triacylglycerols to lipase. Through modification of the cholesterol and triacylglycerol reagents, the carry-over effect was practically eliminated.

5. The recovery of the assigned values of control sera showed average values between 99 and $104 \%$. For bilirubin, creatinine, creatine kinase and alanine aminotransferase some control sera showed deviations greater than $10 \%$.

6. In all cases, regression analysis of the results obtained in comparisons of the present instrument with the Hitachi 705 or 737 yielded slopes close to unity with extreme values of 0.95 and 1.06 . 
7. During the entire evaluation period there was no malfunction or breakdown of the instruments.

The evaluators came to the conclusion that the analytical performance as well as the reliability and practicability of the Hitachi 704 can be rated as excellent.

\section{Introduction}

To establish reliable performance criteria, the Boehringer Mannheim/Hitachi 704 analysis system ${ }^{1}$ ) was evaluated in a multicentre study. Four clinical laboratories participated in the evaluation. The evaluation protocol mainly follows the ECCLS guidelines for the evaluation of analysers in clinical chemistry (1). These guidelines have already been applied successfully to the multicentre evaluation of the Hitachi 737 (2).

This is the first time that a multicentre trial has been undertaken at three different measuring temperatures. This entailed a certain risk with regard to the comparability of the data, especially the enzyme activities.

To ensure uniformity between the different laboratories, similar instruments (Hitachi 705 and 737 resp.) were used for comparison.

These instruments were chosen because of their wide distribution together with their good performance and acceptance. Moreover, these instruments are already installed for routine analysis in the four laboratories.

Within four months, more than 40000 data had been collected in the four centres and statistically evaluated at Boehringer Mannheim.

Data were evaluated in four stages:

\section{Familiarization period}

The instrument users were trained by experts of the company. An acceptance test was carried out covering imprecision and inaccuracy with 3 control sera and a minimum of 4 parameters.

\section{Initial trial}

An imprecision study was carried out for 10 days on the Hitachi 704 and the comparison instrument, using the same 10 analytes as in the main trial.

\section{Main trial}

Extensive performance data were obtained from the main trial, which involved imprecision studies, recovery studies, method comparisons, linearity studies, carry-over and drift experiments for 10 analytes. In contrast to the ECCLS-protocol, the within-run im-

1) Abbreviated to Hitachi 704 in the following text. precision was determined only on one day instead of three, and the between day impreqision data from both the initial and main trial were used.

\section{Description of the Hitachi 704}

The Hitachi 704 is a discrete, selectively operated multitest analyser, which can handle up to 23 chemical analytes including the electrolytes sodium, potassium and chloride; these are determined with an optional ion-selective electrode module. The Hitachi 704 was developed as a logical successor of the Hitachi 705, offering additional special features: an alphanumeric keyboard and improved printout, a real time quality control program, data monitoring and special software for immunological tests (non-linear curve fitting, prozone check). A bidirectional link with a host computer is possible.

The Hitachi 704 is available in 4 versions: a basic model with $37^{\circ} \mathrm{C}$ measuring temperature only, a model with cooling unit and three measuring temperatures $\left(25,30,37^{\circ} \mathrm{C}\right)$ and both of these versions with an ISE-unit. For the multicentre evaluation the model with cooling unit was used. ISEs were tested in a different laboratory; the results will be published elsewhere. The instrument specificiations are listed in table 1; figure 1 shows the analysis modes of the Hitachi 704. For easy reagent handling special system packs for the Hitachi 704 are available (listed in tab. 2).

\section{Methods}

Materials and general procedure

The reagents used on the Hitachi 704 and the comparison analysers are listed in table 3; table 4 shows the most important application settings. The control sera used in the respective trials are shown in table 5.

The four participants of the multicentre evalutation used the same lot of reagent for each of the ten methods.

Predetermined factors were used in the estimation of enżyme activities; a reagent blank was run daily. The factors were the mean of 5 calibration runs using the calibrator for automated systems (Lot. No. 151.266 )). With the exception of bilirubin, all other substrates were calibrated with a daily freshly prepared calibrator. For the bilirubin assay a fixed factor was determined by 5 calibration runs with the Precibil ${ }^{\circledR}$ control serum (tab. 5).

Measurements were performed at $37^{\circ} \mathrm{C}$ in laboratories 1 and 3 , at $30^{\circ} \mathrm{C}$ in laboratory 4 and at $25^{\circ} \mathrm{C}$ in laboratory 2 .

2) Cat. No. 608 432, Boehringer Mannheim GmbH. 


\section{Type of instrument \\ 2 Test channels \\ 3 Test procedures}

6 Sample pipettor

7 Reagent cooling

8 Reagent bottles

9 Reagent dispenser

10 Mixing procedure

11 Reaction rotor

12 Reaction cuvettes

13 Reaction cycle

14 Temperature control

15 Photometer

15 Ion-selective electrodes

16 Data processing

17. Water supply

19 Relative humidity

20 Physical dimensions
Discrete selective multianalyser.

20; with optional ISE-module 23.

Endpoint, endpoint with sample blank, kinetic with serum or substrate start, fixed-time kinetic, combination of two endpoint tests, endpoint and kinetic tests, two kinetic tests, performing two tests in one cuvette, two prozone check procedures, ISE, linear and non-linear calibration, isoenzyme calibration, serum-indices (indicating haemolytic, lipaemic and icteric specimens).

180 tests, with ISE 360 tests, additionally 60 tests with a TWIN-test reagent (two tests in one cuvette).

Turntable with 90 positions in total

- 40 in the outer ring for routine samples

- 30 in the middle ring for standards/calibrators

- 20 in the inner ring for control material, ISE calibrator, stat samples and washing solution Sample cups with $2 \mathrm{ml}$ maximum volume can be used. The minimum sample volume depends on the number of requested tests, on average $50 \mu \mathrm{l}$

$3-20 \mu l$ per test, $20 \mu$ for ISE.

Imprecision $<1 \%$.

Optional. Cold water circuit, refrigerator temperature $5-15^{\circ} \mathrm{C}$.

23 and $50 \mathrm{ml}$ sizes.

1 reagent pipettor for dispensing reagents 1 and 2: $50-500 \mu \mathrm{l}$.

1 stirrer mixes the reaction solution after addition of reagents 1 and 2 .

Turntable; one rotation ( 49 cuvettes +1$)$ in 20 seconds $=1$ working cycle.

48 polyacryl cuvettes, disposable. Volume required: minimum $350 \mu$ l, maximum $700 \mu l$. Optical path length: $6 \mathrm{~mm}$.

10 minutes; addition of reagent 2: 5 minutes after reagent 1.

Water bath $37 \pm 0.1^{\circ} \mathrm{C}$. With cooling unit 25,30 and $37^{\circ} \mathrm{C}$.

o Single beam photometer with 11 available wavelengths: $340,376,415,450,480,505,546$, $570,600,660$ and $700 \mathrm{~nm}$; mono- or bichromatic measurement with freely selectable wavelength combination.

o Light source: halogen lamp.

O Wavelength adjustment: fixed, via a grating chromator, inaccuracy $<2 \mathrm{~nm}$.

O Half band width: $4 \mathrm{~nm}$ in the UV range

$10 \mathrm{~nm}$ in the visible range.

o Photometric range of linearity: $\mathrm{A}=0-2.5$.

o Photometric resolution: $\mathrm{A}=0.0002$.

o Photometric inaccuracy: $\max .1 \%$.

O Indirect potentiometry; flow-through electrode with liquid membrane.

- Reference electrode: $\mathrm{Ag} / \mathrm{AgCl}$.

O Dilution ratio $1: 31$.

O Incubation temperature $37 \pm 0.1{ }^{\circ} \mathrm{C}$, with cooling unit $25,30,37^{\circ} \mathrm{C}$.

o Calibration: automatic 2-point.

O Measuring range: $\mathrm{Na}+80-180 \mathrm{mmol} / \mathrm{l}$,

$$
\mathrm{K}^{+} 1.5-10 \mathrm{mmol} / \mathrm{l} \text {, }
$$$$
\mathrm{Cl}^{-} \text {-60-120 mmol/l. }
$$

O Interface: RS 232 C. Bidirectional link with a host computer is possible.

o Data input: via alphanumeric keyboard and item select keys.

O Data control: CRT-display, 12 inches.

- Data output: printer, 80 characters/line.

○ 2 Floppy disks, $51 / 4$ inches, $1.6 \mathrm{M}$ bytes, 1 system disk and 1 data disk for 400 samples and 40 stats.

O. Reaction monitor for 50 tests.

Internal reservoir with an external supply,

Quality: $\leq 1 \mu \mathrm{S}$,

Consumption during operation: $10 \mathrm{l} / \mathrm{h}$.

$15-27^{\circ} \mathrm{C}$.

$40-80 \%$ at reaction temperature of $37^{\circ} \mathrm{C}$

$40-75 \%$ at $25^{\circ} \mathrm{C}$ or $30^{\circ} \mathrm{C}$.

Width $1.06 \mathrm{~m}$,

Depth $0.78 \mathrm{~m}$,

Height $1.03 \mathrm{~m}$.

approx. $300 \mathrm{~kg}$. 
Fig. 1. Analysis modes of the Hitachi 704 $s=$ sample

$\mathrm{R} 1, \mathrm{R} 2$ : reagent 1,2

M1, M2: mixing 1, 2

$\mathrm{Pi}=$ reading points

*) correction for test 2
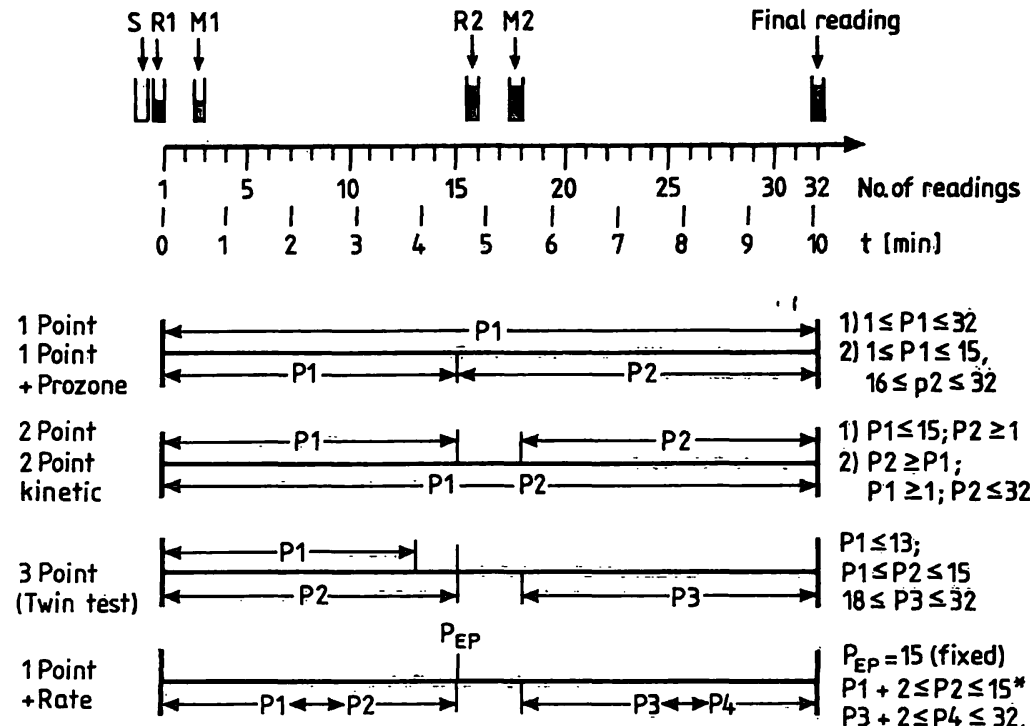

$P 1 \leq 13 ;$

$P 1 \leq P 2 \leq 15$

$18 \leq P 3 \leq 32$

$P_{E P}=15$ (fixed)

$P 1+2 \leq P 2 \leq 15^{*}$

$P 3+2 \leq P 4 \leq 32$

$P 3 \geq 18$

Rate A

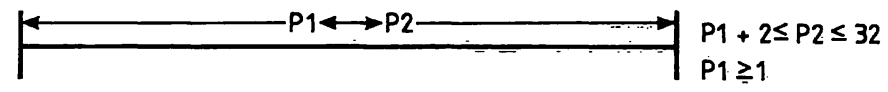

Rate B

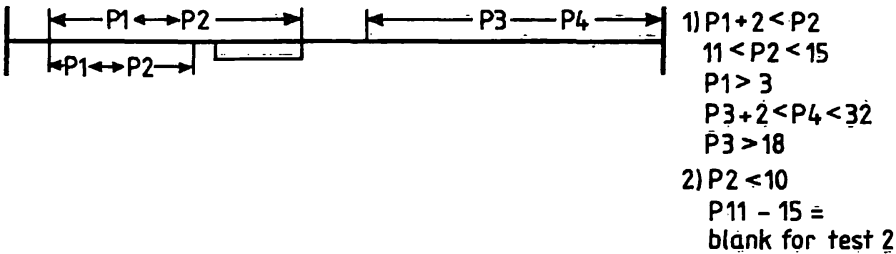

Tab. 2. Available Hitachi 704 system packs

\begin{tabular}{ll}
\hline Enzymes & Substrates \\
\hline Alanine aminotransferase & Albumin \\
Alkaline phosphatase & Bilirubin \\
$\alpha$-Amylase & Bicarbonate \\
Aspartate aminotransferase & Calcium \\
Cholinesterase & Cholesterol \\
Creatinine kinase & Creatinine \\
$\gamma$-Glutamyltransferase & Glucose \\
Lactate dehydrogenase & Iron \\
Lactate dehydrogenase-1- & Total protein \\
isoenzyme ( $\alpha$-HBDH) & Triacylglycerols \\
Lipase & Urea \\
& Uric acid \\
\hline Proteins & TWIN-Tests \\
\hline Immunoglobulins G, A, M & Aspartate/Alanine \\
Transferrin & aminotransferase \\
Complement factors 3,4 & Triacylglycerols/Cholesterol \\
C-reactive protein & Urea/Glucose \\
\hline
\end{tabular}

For some analytes, several methods are available.

\section{Imprecision}

For the within-run imprecision study three different control sera containing three different levels of the corresponding analyte were used (tab. 6). Each participant carried out 21 determinations with each of the analytes. Additionally two fresh human serum pools with different levels of the analytes were measured.

The same control sera were used to establish the between-day imprecision with the Hitachi 704 and the comparison.methods. As the between-day imprecision study of the main trial suc- ceeded directly the initial trial, and both studies were performed under the same conditions, the data of both trials were combined to obtain 21 single data ${ }^{3}$ ). Only the second value of the duplicate measurements was taken for the statistical calculation.

\section{Drift}

Drift effects were studied for all the ten analytes with the same three control sera used in the imprecision trial. Several vials from the same lot were pooled and kept in closed containers in a refrigerator. Small portions were transferred into the sample cups of the analyser 15 minutes before the measurements which were taken hourly over a period of 8 hours. For the bilirubin assay the control material was reconstituted every 2 hours to avoid stability problems of the analyte.

\section{Measuring range and linerarity}

The measuring range and the linearity of the methods were checked by mixing a high level serum - which in some cases had to be spiked - with a low level serum to obtain a series of 10 different concentrations. Fresh reagents were used. The measurements were made on two different days.

\section{Carry-over}

The carry-over caused by the sample probe was studied in detail according to a model of Broughton (18). Five successive portions of a specimen with a high value $\left(h_{1} \ldots, h_{5}\right)$ followed by 5 successive portions of one with a low value $\left(l_{1} \ldots, l_{s}\right)$ were determined ten times for each of the analytes.

${ }^{3}$ ) Twenty days in laboratory 1 , and eleven days in laboratory 4 for the comparison instrument Hitachi 705. 
Tab. 3. Reagents used during the multicentre evaluation.

\begin{tabular}{|c|c|c|c|c|c|}
\hline \multirow[t]{2}{*}{ Analyte } & \multirow[t]{2}{*}{ Method } & \multirow[t]{2}{*}{ References } & \multicolumn{3}{|c|}{ Cat-No., Boehringer Mannheim GmbH } \\
\hline & & & Hitachi 704 & Hitachi 705 & Hitachi 737 \\
\hline $\begin{array}{l}\text { Alanine aminotransferase } \\
\text { EC 2.6.1.2 }\end{array}$ & "opt. stand. method"*) & 3,4 & 816442 & 620076 & $\begin{array}{l}791628 \\
791636\end{array}$ \\
\hline $\begin{array}{l}\alpha \text {-Amylase } \\
\text { EC 3.2.1.1 }\end{array}$ & $\begin{array}{l}\text { Substrate }=p \text {-nitrophenyl- } \\
\alpha-D \text {-maltoheptaoside }\end{array}$ & 5,6 & 704016 & 704016 & $\begin{array}{l}791385 \\
791393\end{array}$ \\
\hline $\begin{array}{l}\text { Creatine kinase } \\
\text { EC } 2.7 .3 .2\end{array}$ & "opt. stand. method"*) & $3,4,7,8$ & 763870 & 763870 & $\begin{array}{l}791474 \\
791482\end{array}$ \\
\hline $\begin{array}{l}\gamma \text {-Glutamyltransferase new } \\
\text { EC } 2.3 .2 .2\end{array}$ & Szasz & 9,10 & 816345 & 620157 & $\begin{array}{l}791644 \\
791652\end{array}$ \\
\hline Bilirubin & $\begin{array}{l}\text { 2,5-Dichlorophenyl- } \\
\text { diazonium salt (DPD) }\end{array}$ & 11 & 816299 & 704148 & $\begin{array}{l}791407 \\
791415\end{array}$ \\
\hline Cholesterol & $\begin{array}{l}\text { Cholesterol oxidase/ } \\
\text { peroxidase }\end{array}$ & 12 & 816302 & 704121 & 791440 \\
\hline Creatinine & $\begin{array}{l}\text { Jaffé without deprotein- } \\
\text { ization }\end{array}$ & 13 & 816426 & 704130 & $\begin{array}{l}791504 \\
781512\end{array}$ \\
\hline Triacylglycerols & $\begin{array}{l}\text { Glycerol-3-phosphate } \\
\text { oxidase/peroxidase }\end{array}$ & 14,15 & 816370 & 704113 & 791768 \\
\hline Urea & $\begin{array}{l}\text { Urease/glutamate } \\
\text { dehydrogenase }\end{array}$ & 16 & 816361 & 773484 & $\begin{array}{l}791695 \\
791709\end{array}$ \\
\hline Uric acid & Uricase/peroxidase & 17 & 816353 & 704156 & $\begin{array}{l}791679 \\
791687\end{array}$ \\
\hline
\end{tabular}

*) "optimized standard method" conforming to the recommendations of the Deutsche Gesellschaft für Klinische Chemie.

Tab. 4. Application settings of the selected methods.

\begin{tabular}{|c|c|c|c|c|c|c|c|c|c|}
\hline \multirow[t]{2}{*}{ Method } & \multicolumn{2}{|c|}{ Wavelengths } & \multirow{2}{*}{$\begin{array}{l}\text { Mea- } \\
\text { suring } \\
\text { points }\end{array}$} & \multirow{2}{*}{$\begin{array}{l}\text { Measuring } \\
\text { mode and time }{ }^{1} \text { ) } \\
(\mathrm{min})\end{array}$} & \multirow{2}{*}{$\begin{array}{l}\text { Reaction } \\
\text { course } \\
\text { incr./ } \\
\text { decr. }^{2} \text { ) }\end{array}$} & \multirow{2}{*}{$\begin{array}{l}\text { Sample } \\
\text { blank }\end{array}$} & \multirow{2}{*}{$\begin{array}{l}\text { Sample } \\
\text { volume } \\
(\mu l)\end{array}$} & \multicolumn{2}{|c|}{ Reagent volume } \\
\hline & $\begin{array}{l}\text { main } \\
(\mathrm{nm})\end{array}$ & $\begin{array}{l}\text { side } \\
(\mathrm{nm})\end{array}$ & & & & & & $\begin{array}{l}\mathrm{Rl} \\
(\mu \mathrm{l})\end{array}$ & $\begin{array}{l}\mathrm{R} 2 \\
(\mu \mathrm{l})\end{array}$ \\
\hline Alanine aminotransferase & 340 & 376 & $19-32$ & $\operatorname{con} 5.9-10$ & decr. & & 20 & 350 & 70 \\
\hline$\alpha$-Amylase & 415 & 660 & $25-32$ & con $7.8-10$ & incr. & & $20 / 10^{3}$ ) & 350 & 70 \\
\hline Creatine kinase & 340 & 376 & $22-32$ & $\operatorname{con} 6.8-10$ & incr. & & 10 & 350 & 70 \\
\hline$\gamma$-Glutamyltransferase & 415 & 660 & $19-32$ & $\operatorname{con} 5.9-10$ & incr. & & 10 & 350 & 70 \\
\hline Bilirubin & 546 & 600 & $15 / 32$ & EP 10 & incr. & + & 10 & 350 & 350 \\
\hline Cholesterol & 505 & 700 & 32 & EP 10 & incr. & - & 5 & 500 & - \\
\hline Creatinine & 505 & 570 & $19-23$ & kin $5.9-7.2$ & incr. & & 20 & 350 & 70 \\
\hline Triacylglycerols & 505 & 700 & 32 & EP 10 & incr. & - & 5 & 500 & - \\
\hline Urea & 340 & 376 & $19-22$ & kin $5.9-6.8$ & decr. & & 5 & 350 & 100 \\
\hline Uric acid & 570 & 660 & 32 & EP 10 & incr. & - & 5 & 100 & 350 \\
\hline
\end{tabular}

1) kin = kinetic mode, EP = Endpoint, con $\equiv$ continuous mode

${ }^{2}$ ) decr. = decreasing, incr. = increasing

3) $10 \mu \mathrm{l}$ at $37^{\circ} \mathrm{C}$

A carry-over constant can be calculated according to the following relation:

$$
\mathrm{K}=\frac{\text { mean }\left(l_{1}-1_{s}\right)}{\operatorname{mean}\left(\mathrm{h}_{5}-1_{s}\right)}(\mathrm{n}=10)
$$

Reagent-related carry-over can be caused by the reagent pipetting system, the stirrer and the cuvettes. Carry-over from the lactate dehydrogenase of the alanine aminotransferase assay to the lactate dehydrogenase assay caused by reagent sampling was checked in one centre. Reagents A and B were pipetted alternately, where $A$ represents the alanine aminotransferase and $B$ the lactate dehydrogenase. For this experiment only, the reagent containing the lactate dehydrogenase (about $3000 \mathrm{U} / \mathrm{l}$; A 1) was pipetted before reagents 1 and 2 of $B$.
Similar studies with other reagent combinations such as cholesterol-uric acid and triacylglycerols-lipase were carried out by the evaluation group of Boehringer Mannheim, and are discussed in the Results section.

\section{Comparison of the analytical procedures}

Accuracy was examined by 3 experiments:

Mean values obtained in the between-day imprecision study were compared:

a) with the assigned values of the three control sera and

b) with the mean value of the comparison method. 
Tab. 5. Control sera chosen for the Hitachi 704 evaluation.

\begin{tabular}{|c|c|c|c|c|c|c|}
\hline \multirow{2}{*}{$\frac{\text { Control serum*) }}{\text { Precinorm }}$} & \multirow{2}{*}{$\begin{array}{l}\text { Lot.-No. } \\
151407,151621 \\
1-595,1-599 \\
1-528\end{array}$} & \multirow[b]{2}{*}{ Analyte } & & & & \\
\hline & & & $\begin{array}{l}\text { Temp. } \\
\left({ }^{\circ} \mathrm{C}\right)\end{array}$ & $\begin{array}{l}\text { CS 1 } \\
\text { Preci- } \\
\text { norm }{ }^{\oplus} \mathrm{U} \\
151621\end{array}$ & $\begin{array}{l}\text { CS } 2 \\
\text { Preci- } \\
\text { path } \\
\text { EV 704*) }\end{array}$ & $\begin{array}{l}\text { CS } 3 \\
\text { Preci- } \\
\text { path }{ }^{\oplus} \\
151464\end{array}$ \\
\hline Precipath U & $\begin{array}{l}151464,150456 \\
150457, \text { EV } 704\end{array}$ & $\begin{array}{l}\text { Alanine amino- } \\
\text { transferase }\end{array}$ & $\begin{array}{l}25 \\
30\end{array}$ & $\begin{array}{l}30.5 \\
40.0\end{array}$ & & $\begin{array}{l}79.5 \\
107\end{array}$ \\
\hline Precinorm ${ }^{\oplus} \mathrm{E}$ & $3-372,151935$ & $(\mathrm{U} / \mathrm{l})$ & 37 & 55.5 & 121 & 146 \\
\hline Precipath E & $3-344,152147$ & $\begin{array}{l}\alpha \text {-Amylase } \\
(\mathrm{U} / \mathrm{l})\end{array}$ & 25 & $\begin{array}{l}214 \\
281\end{array}$ & 300 & $\begin{array}{l}391 \\
523\end{array}$ \\
\hline Precilip & $\begin{array}{l}1-376,150817 \\
151661\end{array}$ & & 37 & 398 & 568 & 739 \\
\hline $\begin{array}{l}\text { Precilip }{ }^{\circledast L} \\
\text { Precibil }\end{array}$ & $1-308,153302$ & $\begin{array}{l}\text { Creatine kinase } \\
(\mathrm{U} / \mathrm{l})\end{array}$ & $\begin{array}{l}25 \\
30 \\
37\end{array}$ & $\begin{array}{l}111 \\
168 \\
258\end{array}$ & $\begin{array}{l}180 \\
\frac{414}{4}\end{array}$ & $\begin{array}{l}212 \\
319 \\
489\end{array}$ \\
\hline $\begin{array}{l}\text { (Boehringer Mannheim GmbH, Mannheim } \\
M+\text { D Moni-trol I }\end{array}$ & 204 & $\begin{array}{l}\gamma \text {-Glutamyl- } \\
\text { transferase } \\
(\mathrm{U} / \mathrm{l})\end{array}$ & $\begin{array}{l}25 \\
30 \\
37\end{array}$ & $\begin{array}{l}34.0 \\
43.0 \\
57.0\end{array}$ & $\frac{63.0}{103}$ & $\begin{array}{l}116 \\
148 \\
192\end{array}$ \\
\hline $\begin{array}{l}\text { M + D Moni-trol II } \\
\text { (AHS/Deutschland GmbH, Bereich Merz }\end{array}$ & $\begin{array}{l}104 \\
+ \text { Dade }\end{array}$ & $\begin{array}{l}\text { Bilirubin } \\
(\mu \mathrm{mol} / \mathrm{l})\end{array}$ & 37 & 39.2 & 75.3 & 105 \\
\hline FRG) & 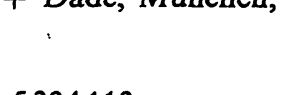 & $\begin{array}{l}\text { Cholesterol } \\
(\mathrm{mmol} / \mathrm{l})\end{array}$ & $\begin{array}{l}37 \\
.\end{array}$ & 2.98 & 5.10 & 2.80 \\
\hline $\begin{array}{l}\text { Validate } \mathrm{N} \\
\text { Validate }^{\boxplus} \mathrm{A}\end{array}$ & $\begin{array}{l}5334113 \\
5345113\end{array}$ & $\begin{array}{l}\text { Creatinine } \\
(\mu \mathrm{mol} / \mathrm{l})\end{array}$ & 37 & 210 & 407 & 345 \\
\hline $\begin{array}{l}\text { (Gödecke AG, Freiburg, FRG) } \\
\text { Kontrollogen }{ }^{\circledR} \text {-L }\end{array}$ & $623124 \mathrm{C}$ & $\begin{array}{l}\text { Triacylglycerols } \\
(\mathrm{mmol} / \mathrm{l})\end{array}$ & 37 & 1.13 & 1.76 & 1.16 \\
\hline $\begin{array}{l}\text { Kontrollogen }{ }^{\oplus} \text {-LP } \\
\text { (Behringwerke AG, Marburg/Lahn, FRG) }\end{array}$ & $623210 \mathrm{~A}$ & $\begin{array}{l}\text { Urea } \\
\text { (mmol/l) }\end{array}$ & 37 & 8.82 & 18.3 & 24.8 \\
\hline $\begin{array}{l}\text { Seronorm } \\
\text { Pathonorm L }\end{array}$ & $\begin{array}{r}162 \\
20\end{array}$ & $\begin{array}{l}\text { Uric acid } \\
(\mu \mathrm{mol} / \mathrm{l})\end{array}$ & 37 & 306 & 381 & 538 \\
\hline
\end{tabular}

Pathonorm $\mathrm{H}$

20

(E. Merck AG, Darmstadt, FRG)

*) The Precinorm ${ }^{\circledR} 151621$, Precipath ${ }^{\oplus}$ EV 704 and Precipath $^{\$} \mathrm{U} 151464$ were used as control sera 1, 2 and 3 in the imprecision and recovery studies.

In a second experiment, up to 25 different control sera (dependent on the analyte) were measured in duplicate assays with the Hitachi 704 and the comparison method. The recoveries of the assigned value were calculated and compared with those for the comparison method.

Each of the 4 laboratories analysed 100 fresh human sera (10 sera per day for 10 days), covering the entire analytical range for each of the 10 analytes with the Hitachi 704 and the comparison instrument. Both methods were measured in parallel.

\section{Results}

The ten methods were not chosen arbitrarily but were selected with a view to checking as many application settings of the instrument as possible (e.g., wavelength, measuring points, sample and reagent volumes and reaction course). Nearly all performance criteria of the instrument are covered by these ten analytical methods.
Tab. 6. Assigned values of the control sera $1-3$ at 25,30 and $37^{\circ} \mathrm{C}$.

*) enzyme activities for $30^{\circ} \mathrm{C}$ were not declared.

\section{Imprecision}

Figure 2 shows the condensed data for the within-run imprecision of all participants and the three control sera.

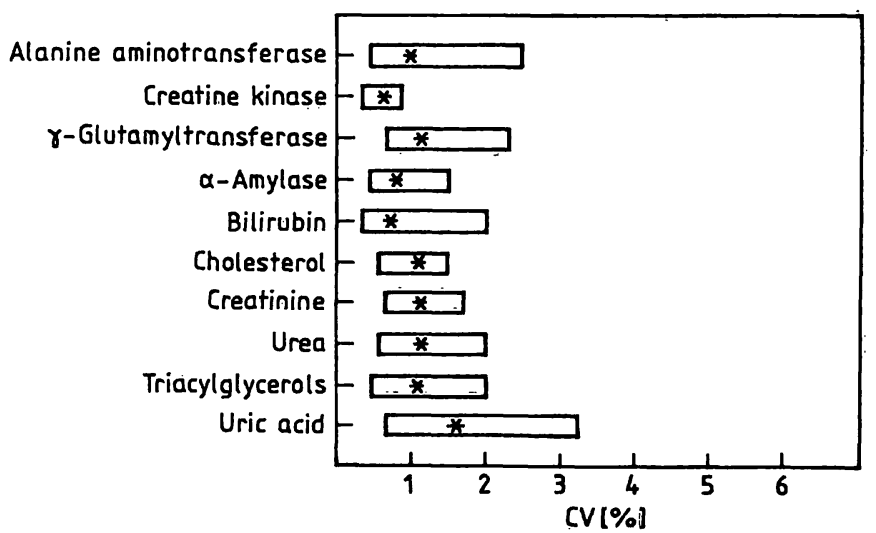

Fig. 2. Within-run imprecision of 4 laboratories and 3 control sera.

For assigned values of the control sera see table 6 .

$\mathrm{CV}=$ coefficient of variation

* = median of the CV's

$\square=$ range of the CV's 
The asterisks respresent the median and the blocks the range of the coefficients of variation ${ }^{4}$ ) for all laboratories and control sera. The median of the $\mathrm{CV}$ for all 10 analytes is equal to or better than $1.6 \%$. Only for alanine aminotransferase, $\gamma$-glutamyltransferase and uric acid does the CV exceed $2 \%(2.5 \%$, $2.3 \%$ and $3.2 \%$ respectively).

Similar results were obtained for the within-run imprecision in human sera. Table 7 shows the data for a normal and pathological serum obtained by the laboratories measuring at $37^{\circ} \mathrm{C}$.

Tab. 7. Within-run imprecision in human sera with the Hitachi 704 at $37^{\circ} \mathrm{C}(\mathrm{n}=21)$.

\begin{tabular}{lcl}
\hline $\begin{array}{l}\text { Analyte } \\
\text { (unit) }\end{array}$ & Mean & $\begin{array}{l}\text { Coefficient of } \\
\text { variation } \% \text { ) }\end{array}$ \\
\hline Alanine aminotransferase & 20 & 2.3 \\
(U/l) & 82 & 0.6 \\
a-Amylase & 97 & 1.5 \\
(U/l) & 143 & 0.8 \\
Creatine kinase & 47 & 1.6 \\
(U/l) & 902 & 0.4 \\
$\gamma$-Glutamyltransferase & 62 & 0.7 \\
(U/l) & 246 & 0.4 \\
Bilirubin & 13.7 & 2.4 \\
( $\mu$ mol/l) & 35.9 & 0.8 \\
Cholesterol & 4.77 & 0.6 \\
(mmol/l) & 11.9 & 0.4 \\
Creatinine & 70.7 & 2.2 \\
( $\mu$ mol/l) & 178 & 1.1 \\
Triacylglycerols & 1.64 & 1.8 \\
(mmol/l) & 4.08 & 0.5 \\
Urea & 5.89 & 2.1 \\
(mmol/l) & 24.3 & 0.9 \\
Uric acid & 168 & 2.5 \\
( $\mu$ mol/l) & 492 & 0.6 \\
\hline & & \\
\hline
\end{tabular}

For the same control sera, figure 3 shows the CV of the between-day imprecision study for the Hitachi 704 and the comparison instrument. The $\mathrm{CV}$ is below $3 \%$ except for alanine-aminotransferase $(3.1 \%)$, bilirubin $(6.5 \%)$, urea (3.5\%) and uric acid (3.9\%). The median of the $\mathrm{CV}$ is around $2 \%(2.8 \%$ for bilirubin and $0.7 \%$ for amylase).

Figure 4 gives a more detailed presentation of the between-day imprecision data for the control sera 1 and 3, for one laboratory in each case. The imprecision of the Hitachi 704 is remarkably better than that of the comparison instruments. This may be the case if a new instrument is compared with one that has been in routine use for years.

4) Abbreviated to CV in the following text.

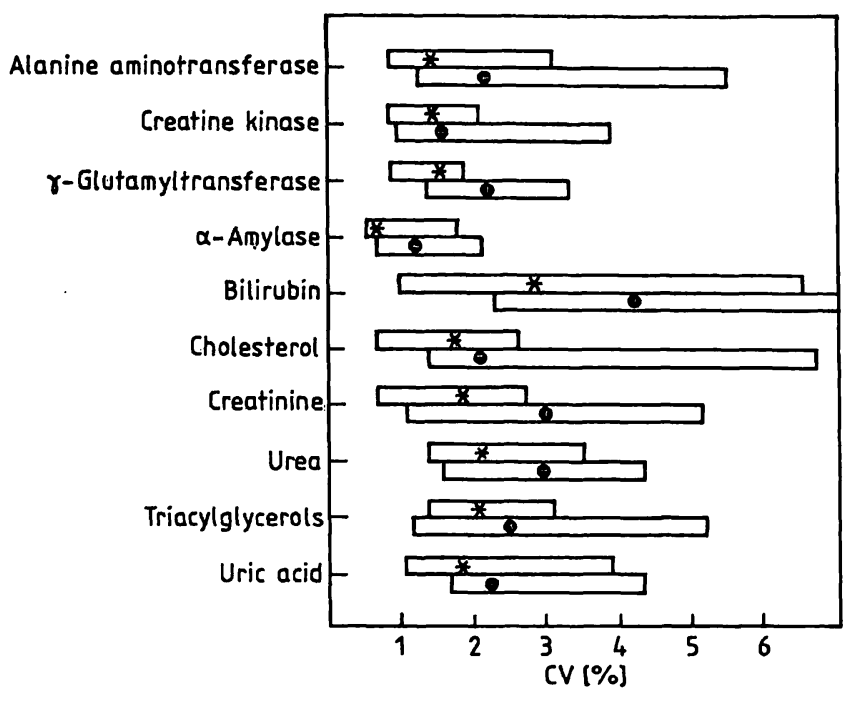

Fig. 3. Between-day imprecision of 4 laboratories and 3 control sera for the Hitachi 704 and the comparison instrument. For assigned values of the control sera see table 6 . $\mathrm{CV}=$ coefficient of variation

* = median of the CV's for the Hitachi 704

0 = median of the CV's for the comparison instrument $\square$ = range of the CV's, upper block for the Hitachi 704, lower block for the comparison instrument

The relatively high CV (maximum $6.5 \%$ ) of bilirubin reflects the instability of this analyte: the bilirubin value is dependent on the influence of light and the reconstitution time of the control serum. Therefore it lends itself poorly to instrument testing unless preanalytical conditions (mainly reconstitution and storage) are standardized.

\section{Drift}

All data have been represented graphically. Only bilirubin in one laboratory shows a severe drift because the pre-analytical conditions were not maintained. For all other methods no drift was found. Figure 5 illustrates the excellent reproducibility for amylase and cholesterol over 8 hours.

\section{Measuring range and linearity}

The linearity study for alanine aminotransferase at $37^{\circ} \mathrm{C}$ is shown in figure 6 . In the left-hand diagram the measured activity is plotted against the target activity, which is obtained by regression calculation of the first 4 points, this being the segment more likely to be linear. The higher values tend to deviate more and more from the identity $y=x$. A better critical examination is possible for the right-hand diagram which shows the relative deviation of measured and expected values. The acceptance criteria for linearity was set at a limit of $\pm 5 \%$ from the expected value. 

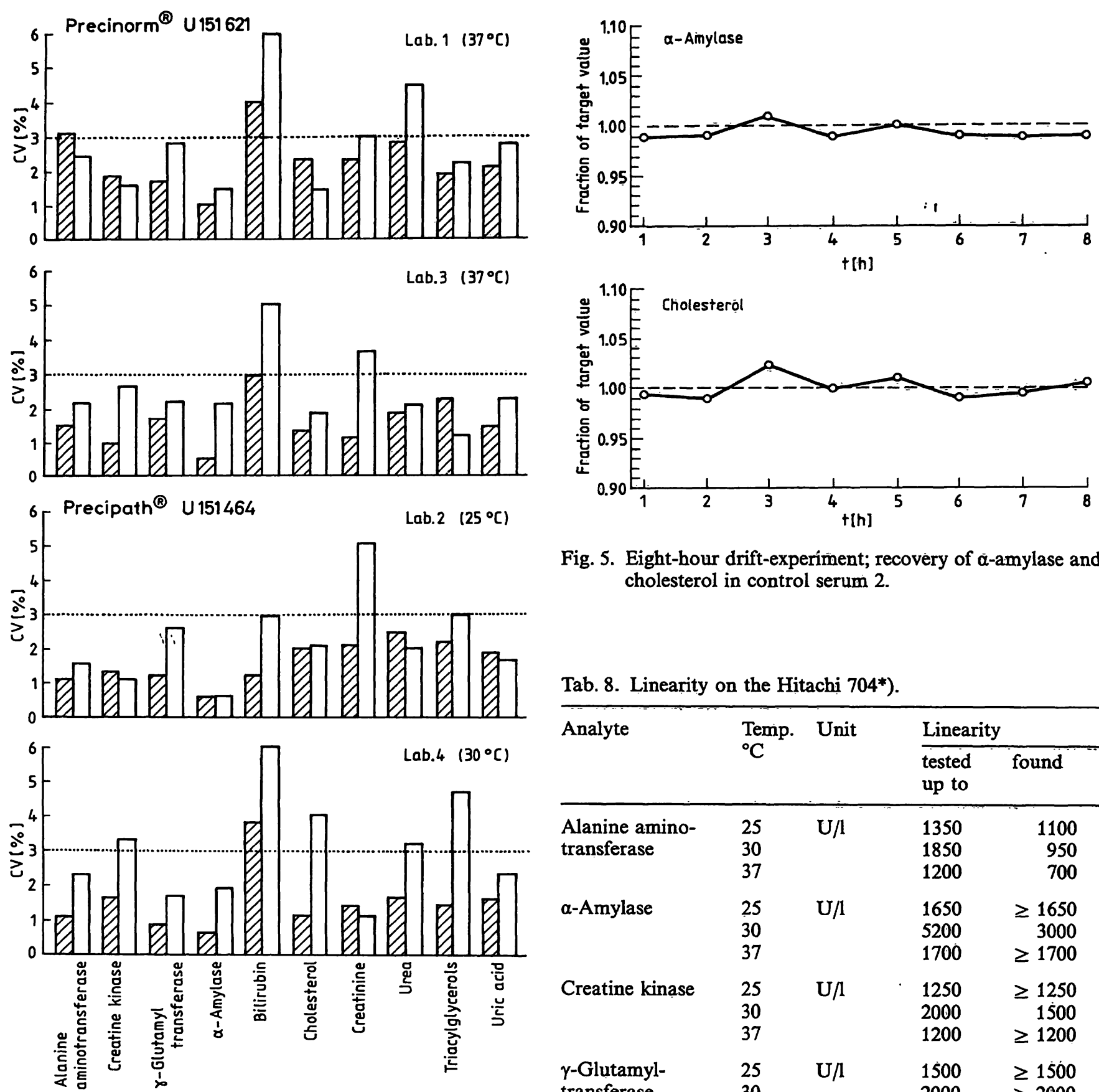

Fig. 5. Eight-hour drift-experiment; recovery of $\alpha$-amylase and cholesterol in control serum 2 .

Tab. 8. Linearity on the Hitachi $\left.704^{*}\right)$.

\begin{tabular}{|c|c|c|c|c|}
\hline \multirow[t]{2}{*}{ Analyte } & \multirow{2}{*}{$\begin{array}{l}\text { Temp. } \\
{ }^{\circ} \mathrm{C}\end{array}$} & \multirow[t]{2}{*}{ Unit } & \multicolumn{2}{|c|}{ Linearity } \\
\hline & & & $\begin{array}{l}\text { tested } \\
\text { up to }\end{array}$ & found \\
\hline $\begin{array}{l}\text { Alanine amino- } \\
\text { transferase }\end{array}$ & $\begin{array}{l}25 \\
30 \\
37\end{array}$ & $\mathrm{U} / 1$ & $\begin{array}{l}1350 \\
1850 \\
1200\end{array}$ & $\begin{array}{r}1100 \\
950 \\
700\end{array}$ \\
\hline$\alpha$-Amylase & $\begin{array}{l}25 \\
30 \\
37\end{array}$ & $\mathrm{U} / 1$ & $\begin{array}{l}1650 \\
5200 \\
1700\end{array}$ & $\begin{array}{r}\geq 1650 \\
3000 \\
\geq 1700\end{array}$ \\
\hline Creatine kinase & $\begin{array}{l}25 \\
30 \\
37\end{array}$ & $\mathrm{U} / 1$ & $\begin{array}{l}1250 \\
2000 \\
1200\end{array}$ & $\begin{array}{r}\geq 1250 \\
1500 \\
\geq 1200\end{array}$ \\
\hline $\begin{array}{l}y \text {-Glutamyl- } \\
\text { transferase }\end{array}$ & $\begin{array}{l}25 \\
30\end{array}$ & $\mathrm{U} / 1$ & $\begin{array}{l}1500 \\
2000\end{array}$ & $\begin{array}{l}\geq 1500 \\
\geq 2000\end{array}$ \\
\hline Bilirubin & 30 & $\mu \mathrm{mol} / 1$ & 360 & $\geq 360$ \\
\hline Cholesterol & 25 & $\mathrm{mmol} / \mathrm{l}$ & 25 & $\geq 25$ \\
\hline Creatinine & 25 & $\mu \mathrm{mol} / \mathrm{l}$ & 2100 & $\geq 2100$ \\
\hline Triacylglycerols & 25 & $\mathrm{mmol} / \mathrm{l}$ & 13 & $\geq 13$ \\
\hline Urea & 37 & $\mathrm{mmol} / \mathrm{l}$ & 57 & 47 \\
\hline Uric acid & 25 & $\mu \mathrm{mol} / \mathrm{l}$ & 1370 & 1000 \\
\hline
\end{tabular}

In the given example the $5 \%$ deviation is attained at $700 \mathrm{U} / 1$, i. e. the method is linear up to $700 \mathrm{U} / 1$.

Table 8 summarizes the results of the linearity experiment. The measuring range is shown in the last column while the preceding column represents the values up to which the linearity has been checked. A wide linear measuring range was found, seldom requiring a sample predilution.

Because the linearity was checked with fresh reagents, the linearity limits were even higher than those claimed by the manufacturer.

*) freshly prepared reagents. For the substrates only the highest tested linearity is presented.

\section{Carry-over}

Table 9 shows results from the investigation of sample-related carry-over. Only the highest carry-over recorded by any laboratory for an analyte is reported in this table. The minimal and maximal values of the 

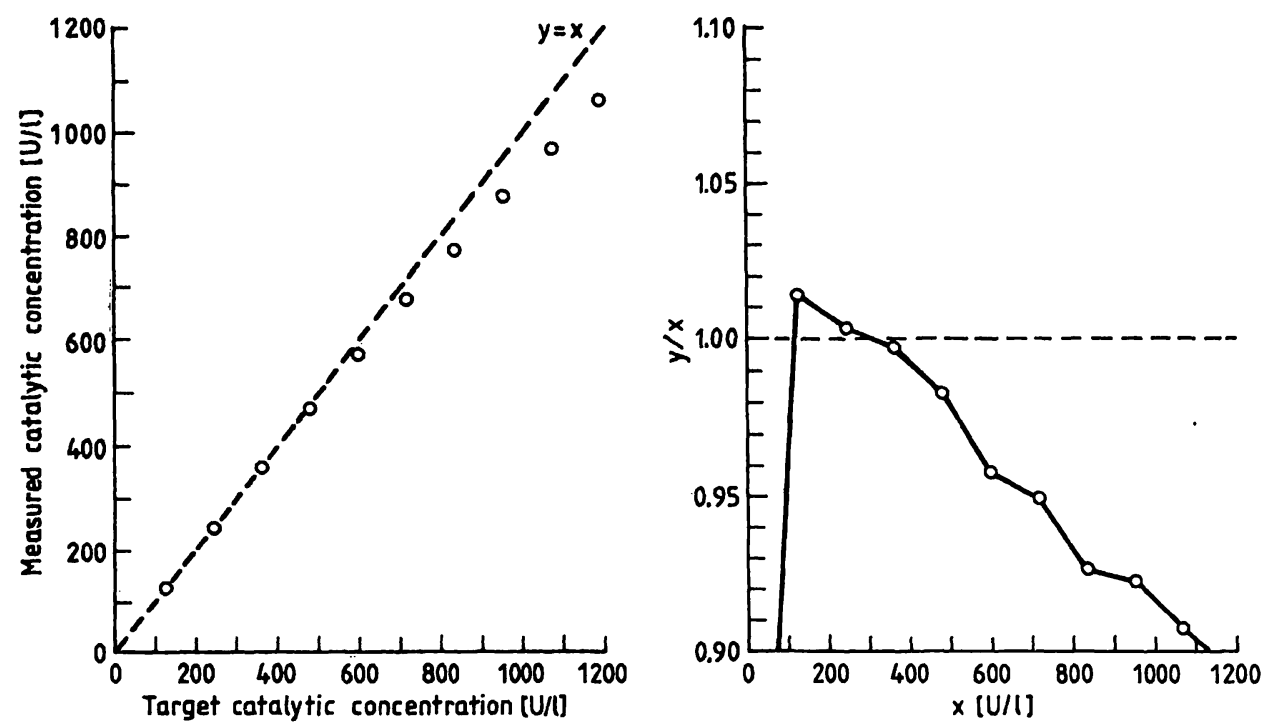

Fig. 6. Linearity of alanine aminotransferase at $37^{\circ} \mathrm{C}$ (lab. 1).

Tab. 9. Sample-related carry-over on the Hitachi 704.

\begin{tabular}{|c|c|c|c|c|c|c|c|c|c|}
\hline \multirow[t]{2}{*}{ Analyte } & \multirow[t]{2}{*}{ Unit } & \multirow{2}{*}{$\begin{array}{l}\text { High } \\
\text { concen- } \\
\text { tration } \\
\mathrm{h}\end{array}$} & \multirow{2}{*}{$\begin{array}{l}\text { Low } \\
\text { concen- } \\
\text { tration } \\
\left.1^{1}\right)\end{array}$} & \multicolumn{3}{|l|}{$l_{1}-l_{5}$} & \multirow{2}{*}{$\begin{array}{l}\text { Standard } \\
\text { devia- } \\
\text { tion }{ }^{2} \text { of } \\
1_{3}, 1_{4}, 1_{5}\end{array}$} & \multirow{2}{*}{$\begin{array}{l}90 \% \\
\text { range }^{2} \text { ) of } \\
l_{3}, L_{4}, l_{5}\end{array}$} & \multirow{2}{*}{$\begin{array}{l}\text { Carry- } \\
\text { over } \\
\text { constant } \\
\mathrm{K} \cdot 10^{4}\end{array}$} \\
\hline & & & & minimum & median & $\begin{array}{l}\operatorname{maxi}- \\
\text { mum }\end{array}$ & & & \\
\hline Alanine aminotransferase & $\mathrm{U} / 1$ & $>4000$ & 25.1 & -1.7 & 0.3 & 1.5 & 0.59 & 1.95 & 0.35 \\
\hline$\alpha$-Amylase & $\mathrm{U} / 1$ & 2350 & 66.0 & -4.0 & 1.0 & 4.0 & 1.98 & 5.5 & 0.88 \\
\hline Creatine kinase & $\mathrm{U} / 1$ & 2100 & 33.0 & -1.0 & 0.0 & 1.0 & 0.52 & 2.0 & -0.48 \\
\hline$\gamma$-Glutamyltransferase & $\mathbf{U} / 1$ & 170 & 24.0 & -2.4 & 0.0 & 2.4 & 0.95 & 2.7 & 12.1 \\
\hline Bilirubin & $\mu \mathrm{mol} / 1$ & 650 & 10.1 & -0.86 & -0.26 & 0.86 & 0.80 & 2.14 & -2.1 \\
\hline Cholesterol & $\mathrm{mmol} / 1$ & 11.9 & 2.25 & -0.03 & 0.0 & 0.05 & 0.02 & 0.05 & 0 \\
\hline Creatinine & $\mu \mathrm{mol} / 1$ & 1079 & 76.9 & -2.7 & 0.0 & 2.7 & 1.59 & 6.2 & 0 \\
\hline Triacylglycerols & $\mathrm{mmol} / \mathrm{l}$ & 12.0 & 0.62 & -0.01 & 0.0 & 0.29 & 0.05 & 0.14 & 26.0 \\
\hline Urea & $\mathrm{mmol} / 1$ & 35.0 & 2.83 & -0.17 & 0.0 & 0.50 & 0.20 & 0.58 & 15.4 \\
\hline Uric acid & $\mu \mathrm{mol} / 1$ & 803 & 334 & -14.3 & -1.8 & 9.5 & 8.7 & 24.1 & -13.0 \\
\hline
\end{tabular}

$\left.{ }^{1}\right)$ median of the ten values of $l_{3}, l_{4}$ and $l_{5}$

2) $n=30$

difference $l_{1}-l_{5}$ as well as the median of the ten series are reported. In all cases the median is less than the standard deviation of the low concentration. If the maximal value of the difference $l_{1}-l_{5}$ is compared with the $90 \%$ range of the low concentration, the difference is lower than the range, except for triacylglycerols (twice the range). But this poor result for triacylglycerols was found in only one of the ten series, so that the occurrence of systematic carry-over cannot be claimed.

We think that the comparison of the interference effect with the imprecision of the uninfluenced low values is more illustrative than the carry-over constant. As the carry-over effect is within the noise level of the determination of the respective analyte, the difference often becomes negative.

Reagent-dependent carry-over for the combination alanine aminotransferase to lactate dehydrogenase is negligible, values showing less than $10 \mathrm{U} / 1$ at $37^{\circ} \mathrm{C}$, i.e. less than $3 \%$ of the reference limit.
A carry-over caused by both the reagent pipettor and the cuvettes was found with the system cholesterol to uric acid. The uric acid results are increased by about $7.8 \mu \mathrm{mol} / 1$ at $37^{\circ} \mathrm{C}$, if this assay is performed after a cholesterol assay, or in a cuvette which has previously been used for a cholesterol test. The cholesterol oxidase is responsible because it affects the colorimetric reagent of the uric acid test. Boehringer Mannheim has modified this enzyme, so that the carry-over is now negligible.

The lipase result is increased about $600 \mathrm{U} / 1$ if a lipase assay is performed after a triacylglycerol test. This is due to the lipase activity of the triacylglycerol reagent. In the past it was recommended that the lipase assay should be run in batch-mode and with a separate cuvette ring. The latter is not necessary if the triacylglycerol test is programmed so that the reaction takes place in the first 5 minutes of the reaction cycle and then hydrochloric acid is added to deactivate the lipase in the reaction mixture. The sample carry-over 
can be avoided, if both channels are separated from each other and a lipase assay is never requested after a triacylglycerol test. Taking these points into consideration the lipase assay can then be performed in the usual selective mode.

\section{Comparison of analytical procedures}

\section{Recovery of the assigned value in control samples}

Figure 7 shows the recovery of assigned values for control serum 1. These results were obtained from the mean of the between-day imprecision ( $n=20$ or 21 ; 2nd of the duplicate measurements). Only the urea and uric acid recoveries in laboratories 2 and 3, respectively, are clearly outside the $\pm 5 \%$ limit, although they are within the $\pm 10 \%$ range. Similar results were found with the other two control sera.

Table 10 summarizes the results of the recovery studies in 25 different control sera. The mean recovery (median) is very close to $100 \%$ for all analytes with extreme values of 99 and $104 \%$. Hence the majority of deviations from the assigned value is within $\pm 5 \%$. A more marked deviation can be seen in the case of creatine kinase, with $7 \%$ of the values (4 labs with 20 to 25 sera) deviating more than $20 \%$ from the assigned value. This is possibly due to the specific composition of control sera from different sources, and the dependency on the reconstitution time. The deviations (more than $10 \%$ ) in the case of bilirubin can be explained by the instability of the analyte. The target value of creatinine is dependent on the method. For both analytes the agreement with the comparison instrument is good.

It should be mentioned that these results were established by a single experiment, whereas the mean of several independent series should be chosen for the examination of the accuracy.

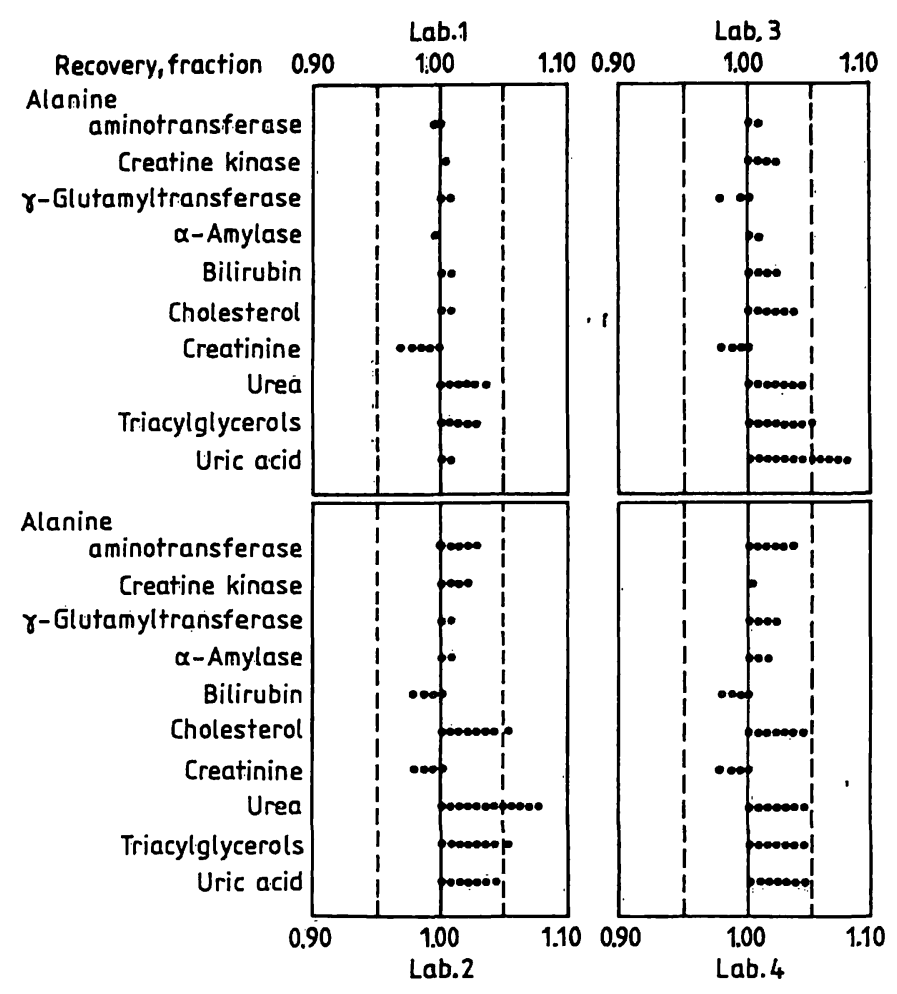

Fig. 7. Recovery of assigned values for control serum 1 (lab. 1 to 4).

\section{Method comparison with patient specimens}

The statistical evaluation by a non-parametric method of Passing \& Bablok $(19,20)$ yielded slopes for the regression line which are close to unity in all cases with extreme values of 0.95 and 1.06. The intercepts are negligible (see tab. 11). The medians of the relative differences do not show any significant deviations from the comparison method. The results reflect close agreement with the comparison instrument, i.e. the established laboratory method.

Plots for the comparison of methods are shown in figure 8. To improve the graphical presentation, not all figures show the whole measuring range.

Tab. 10. Recovery in 25 different control sera.

Distribution of the recoveries (in \%) as a function of the \% deviation from assigned value.

\begin{tabular}{|c|c|c|c|c|c|c|}
\hline \multirow[t]{3}{*}{ Analyte } & \multirow{3}{*}{$\begin{array}{l}\text { Mean recovery } \\
\text { (median) of } \\
\text { assigned values } \\
\text { in } \%\end{array}$} & \multicolumn{5}{|c|}{$\%$ Deviation from assigned value } \\
\hline & & $0-<5$ & $5-<10$ & $10-<15$ & $15-<20$ & $\geq 20$ \\
\hline & & \multicolumn{5}{|c|}{ Distribution of the recoveries in \% } \\
\hline Alanine aminotransferase & 103 & 51 & 36 & 9 & 3 & 1 \\
\hline$\alpha$-Amylase & 101 & 89 & 9 & 1 & 0 & 0 \\
\hline Creatine kinase & 101 & 81 & 12 & 0 & 0 & $\overline{7}$ \\
\hline$\gamma$-Glutamyltransferase & 101 & 88 & 9 & 3 & 0 & 0 \\
\hline Bilirubin & 102 & 58 & 23 & 15 & 4 & 0 \\
\hline Cholesterol & 104 & 66 & 31 & 3 & 0 & 0 \\
\hline Creatínine & 99 & 69 & 19. & 10 & 2 & 0 \\
\hline Triacylglycerols & 103 & 55 & 35 & 7 & 3 & 0 \\
\hline Urea & 101 & 81 & 16 & 2 & 1 & 0 \\
\hline Uric acid & 104 & 69 & 27. & 2 & 2 & 0 \\
\hline
\end{tabular}


Tab. 11. Method comparison with human sera on the Hitachi $704(y)$ and comparison instrument (x) (Hitachi 705, Lab. 1, 3, 4 and Hitachi 737, Lab. 2; $n=100$ ).

\begin{tabular}{|c|c|c|c|c|c|c|c|}
\hline \multirow{2}{*}{$\begin{array}{l}\text { Analyte } \\
\text { (Unit) } \\
\begin{array}{l}\text { Alanine aminotransferase } \\
(\mathrm{U} / \mathrm{l})\end{array}\end{array}$} & \multirow{2}{*}{$\begin{array}{l}\text { Lab. } \\
\\
1 \\
3 \\
2 \\
4\end{array}$} & \multirow{2}{*}{$\begin{array}{l}\text { Temp. } \\
\text { ('C) } \\
\\
37 \\
37 \\
25 \\
30\end{array}$} & \multicolumn{2}{|c|}{$\begin{array}{l}\text { Range } \\
\text { (from } x \text { ) }\end{array}$} & \multicolumn{2}{|c|}{$\begin{array}{l}\text { Regression } \\
\text { analysis } \\
y=b x+a \\
b\end{array}$} & \multirow{2}{*}{$\begin{array}{l}\text { Median } \\
\text { rel. diff. } \\
\begin{array}{l}\text { (\%) } \\
\end{array} \\
-0.47 \\
3.86 \\
0.00 \\
3.29\end{array}$} \\
\hline & & & $\begin{array}{l}4 \\
7 \\
3 \\
5\end{array}$ & $\begin{array}{l}-465 \\
-900 \\
-1929 \\
-427\end{array}$ & $\begin{array}{l}0.97 \\
1.03 \\
1.00 \\
1.03\end{array}$ & $\begin{array}{l}0.44 \\
0.47 \\
0.00 \\
0.32\end{array}$ & \\
\hline $\begin{array}{l}\text { a-Amylase } \\
(\mathrm{U} / \mathrm{I})\end{array}$ & $\begin{array}{l}1 \\
3 \\
2 \\
4\end{array}$ & $\begin{array}{l}37 \\
37 \\
25 \\
30\end{array}$ & $\begin{array}{r}23 \\
9 \\
13 \\
36\end{array}$ & $\begin{array}{l}-1235 \\
-2206 \\
-3906 \\
-630\end{array}$ & $\begin{array}{l}0.98 \\
1.04 \\
1.00 \\
1.03\end{array}$ & $\begin{array}{r}1.00 \\
-1.25 \\
0.00 \\
-0.97\end{array}$ & $\begin{array}{r}-0.82 \\
2.74 \\
0.00 \\
2.52\end{array}$ \\
\hline $\begin{array}{l}\text { Creatine kinase } \\
(\mathrm{U} / \mathrm{l})\end{array}$ & $\begin{array}{l}1 \\
3 \\
2 \\
4\end{array}$ & $\begin{array}{l}37 \\
37 \\
25 \\
30\end{array}$ & $\begin{array}{r}4 \\
27 \\
4 \\
8\end{array}$ & $\begin{array}{l}-1101 \\
-1859 \\
-1037 \\
-3200\end{array}$ & $\begin{array}{l}0.99 \\
1.02 \\
0.99 \\
0.96\end{array}$ & $\begin{array}{r}1.77 \\
0.53 \\
-1.82 \\
2.79\end{array}$ & $\begin{array}{r}1.47 \\
2.15 \\
-6.25 \\
-2.22\end{array}$ \\
\hline $\begin{array}{l}\gamma \text {-Glutamyltransferase } \\
(\mathrm{U} / \mathrm{I})\end{array}$ & $\begin{array}{l}1 \\
3 \\
2 \\
4\end{array}$ & $\begin{array}{l}37 \\
37 \\
25 \\
30\end{array}$ & $\begin{array}{l}7 \\
6 \\
3 \\
6\end{array}$ & $\begin{array}{l}-728 \\
-1872 \\
-951 \\
-1900\end{array}$ & $\begin{array}{l}1.02 \\
1.01 \\
0.95 \\
1.00\end{array}$ & $\begin{array}{l}0.92 \\
0.80 \\
0.16 \\
0.00\end{array}$ & $\begin{array}{r}2.76 \\
2.01 \\
-5.17 \\
0.00\end{array}$ \\
\hline $\begin{array}{l}\text { Bilirubin } \\
\text { ( } \mu \mathrm{mol} / 1)\end{array}$ & $\begin{array}{l}1 \\
3 \\
2 \\
4\end{array}$ & $\begin{array}{l}37 \\
37 \\
25 \\
30\end{array}$ & $\begin{array}{l}6 \\
1,5 \\
1,7 \\
3\end{array}$ & $\begin{array}{l}-775 \\
-451 \\
-296 \\
-397 .\end{array}$ & $\begin{array}{l}1.06 \\
0.97 \\
0.96 \\
1.04\end{array}$ & $\begin{array}{r}-0.68 \\
-0.34 \\
0.68 \\
-0.51\end{array}$ & $\begin{array}{r}2.11 \\
-3.47 \\
1.00 \\
1.92\end{array}$ \\
\hline $\begin{array}{l}\text { Cholesterol } \\
(\mathrm{mmol} / \mathrm{l})\end{array}$ & $\begin{array}{l}1 \\
3 \\
2 \\
4\end{array}$ & $\begin{array}{l}37 \\
37 \\
25 \\
30\end{array}$ & $\begin{array}{l}0.9 \\
3.2 \\
1.4 \\
1.2\end{array}$ & $\begin{array}{l}3-10.0 \\
6-\quad 15.0 \\
0-\quad 24.4 \\
6-\quad 14.3\end{array}$ & $\begin{array}{l}1.00 \\
1.00 \\
0.98 \\
1.00\end{array}$ & $\begin{array}{l}0.00 \\
0.03 \\
0.03 \\
0.03\end{array}$ & $\begin{array}{r}0.00 \\
0.32 \\
-1.35 \\
0.48\end{array}$ \\
\hline $\begin{array}{l}\text { Creatinine } \\
(\mu \mathrm{mol} / \mathrm{l})\end{array}$ & $\begin{array}{l}1 \\
3 \\
2 \\
4\end{array}$ & $\begin{array}{l}37 \\
37 \\
25 \\
30\end{array}$ & $\begin{array}{l}24.8 \\
61.9 \\
44.2 \\
26\end{array}$ & $\begin{array}{l}-1048 \\
-1676 \\
-1087 \\
-674\end{array}$ & $\begin{array}{l}1.02 \\
1.02 \\
1.02 \\
1.04\end{array}$ & $\begin{array}{l}-0.88 \\
-1.77 \\
-0.88 \\
-2.65\end{array}$ & $\begin{array}{l}0.40 \\
0.81 \\
1.28 \\
2.85\end{array}$ \\
\hline $\begin{array}{l}\text { Triacylglycerols } \\
(\mathrm{mmol} / \mathrm{l})\end{array}$ & $\begin{array}{l}1 \\
3 \\
2 \\
4\end{array}$ & $\begin{array}{l}37 \\
37 \\
25 \\
30\end{array}$ & $\begin{array}{l}0.4 \\
0.4 \\
0.4 \\
0.3\end{array}$ & $\begin{array}{lc}3- & 9.1 \\
0- & 15.5 \\
9- & 29.1 \\
5- & 9.67\end{array}$ & $\begin{array}{l}1.01 \\
1.00 \\
1.02 \\
1.02\end{array}$ & $\begin{array}{r}0.00 \\
0.04 \\
0.02 \\
-0.01\end{array}$ & $\begin{array}{l}1.28 \\
1.59 \\
2.87 \\
1.48\end{array}$ \\
\hline $\begin{array}{l}\text { Urea } \\
(\mathrm{mmol} / \mathrm{l})\end{array}$ & $\begin{array}{l}1 \\
3 \\
2 \\
4\end{array}$ & $\begin{array}{l}37 \\
37 \\
25 \\
30\end{array}$ & $\begin{array}{l}2.5 \\
3.5 \\
2.5 \\
1.5\end{array}$ & $\begin{array}{l}0-45.0 \\
0-\quad 55.8 \\
0-\quad 25.0 \\
0-\quad 43.2\end{array}$ & $\begin{array}{l}1.00 \\
1.03 \\
1.00 \\
1.04\end{array}$ & $\begin{array}{r}-0.17 \\
-0.21 \\
0.00 \\
0.06\end{array}$ & $\begin{array}{r}-2.49 \\
1.37 \\
0.00 \\
4.62\end{array}$ \\
\hline $\begin{array}{l}\text { Uric acid } \\
(\mu \mathrm{mol} / \mathrm{l})\end{array}$ & $\begin{array}{l}1 \\
3 \\
2 \\
4\end{array}$ & $\begin{array}{l}37 \\
37 \\
25 \\
30\end{array}$ & $\begin{array}{r}79 \\
175 \\
119 \\
31\end{array}$ & $\begin{array}{l}-767 \\
-1122 \\
-660 \\
-861\end{array}$ & $\begin{array}{l}1.05 \\
1.00 \\
1.00 \\
1.01\end{array}$ & $\begin{array}{r}-11.30 \\
7.14 \\
0.00 \\
-0.59\end{array}$ & $\begin{array}{l}1.39 \\
1.39 \\
0.00 \\
0.43\end{array}$ \\
\hline
\end{tabular}

\section{Interferences}

Since the multicentre evaluation was primarily concerned with the Hitachi 704 instrument and not with the reagents applied to it, interference studies were not carried out.

\section{Assessment of practicability}

In addition to the analytical performance, characteristics such as reliability, practicability and integration into the laboratory organisation are important for the evaluation of an analytical instrument. These attri- butes cannot be measured accurately and no general evaluation protocol can be applied. Nevertheless, these points should be observed during the evaluation period. Only a brief summary of the impressions will be presented in the following.

No problems were associated with the installation of the Hitachi 704. The laboratory staff was well acquainted with the instrument within two days, which is normal for an operator with experience on other Hitachi analysers. The instrument can be operated easily, and the data input is very simple. However, the characters of the keyboard are arranged alpha- 

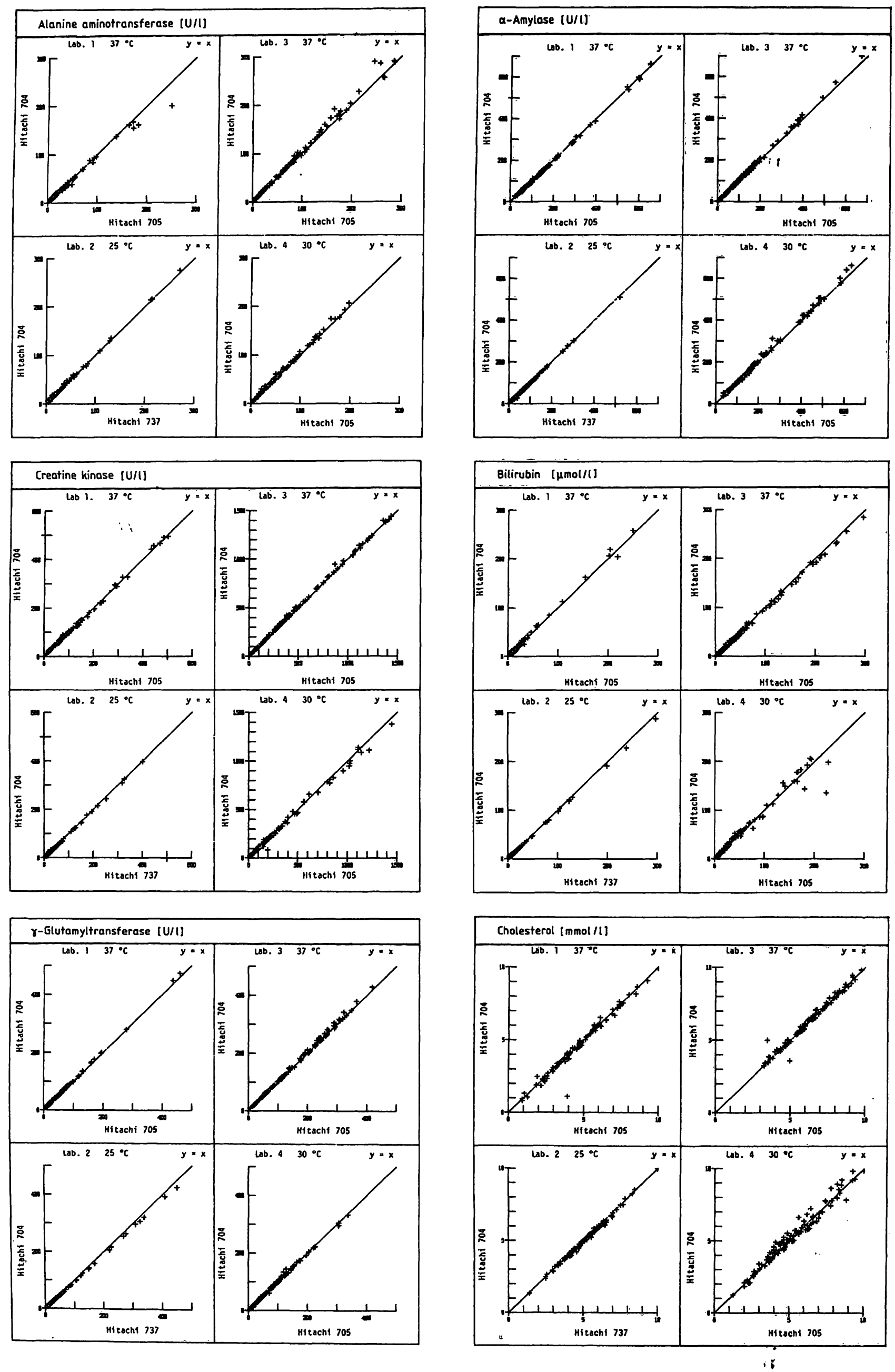

J. Clin. Chem. Clin. Biochem. / Vol. 25, 1987 / No. 12 

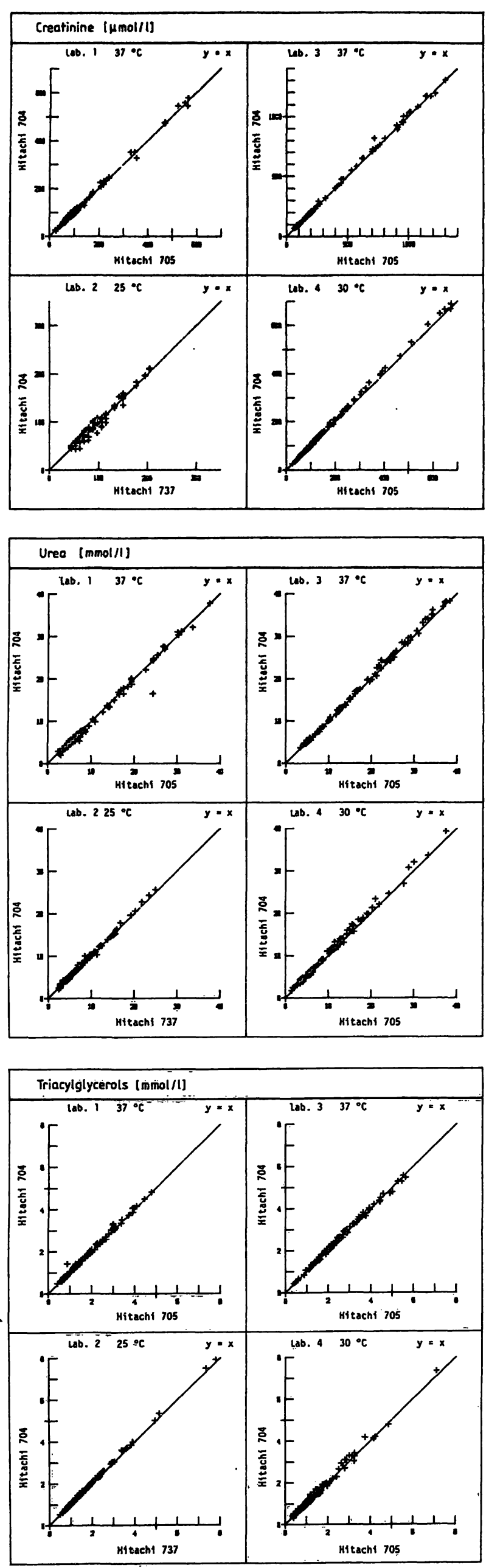

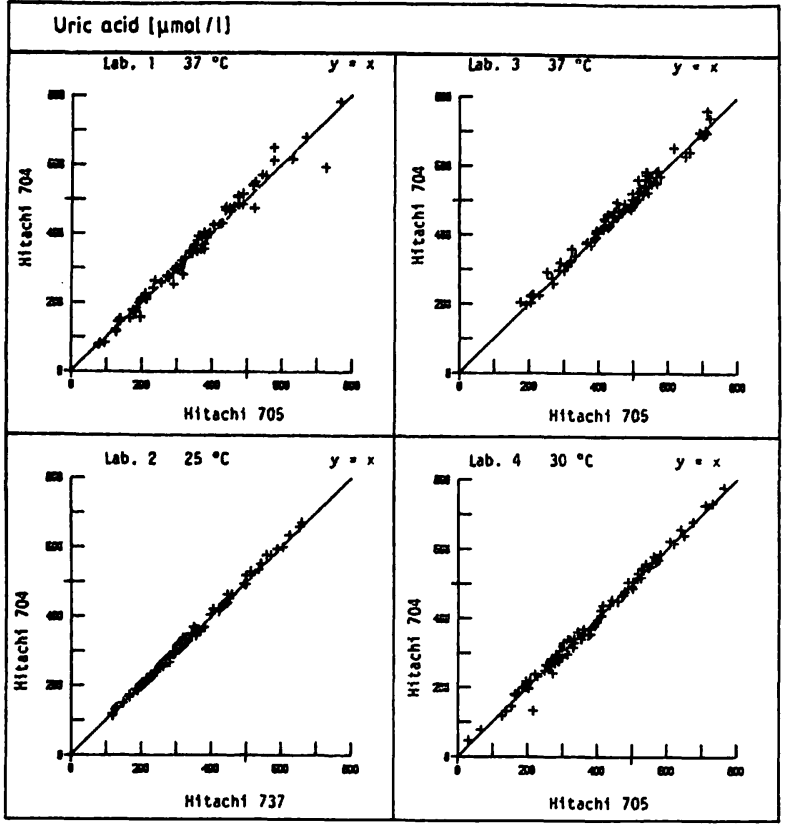

Fig. 8. Method comparison from 4 laboratories.

betically, which is unusual for users who are familiar with the' conventional typewriter keyboard. On the other hand, one can easily get accustomed to this arrangement.

For the frequently requested analytes the reagent bottles are too small for longer series. Boehringer Mannheim will introduce concentrated reagents for more than ten methods so that at least twice the number of determinations per bottle can be made.

The ECCLS-protocol recommends a logbook in which any breakdown or defect of the instrument is recorded. In our case, keeping this logbook was not actually necessary. There were no breakdowns in any of the laboratories at any time during the entire evaluation period. Only during the initial trial in laboratory 4 , was there a problem with the light source of the photometer. This was recognized from the results of the day-to-day imprecision run. After exchange of the lamp, this instrument ran without any fault.

Reliability and practicability, as well as the analytical performance of the Hitachi 704, can be rated as excellent. The Hitachi 704 is well suited for routine operation and emergency analysis in small to mediumsized laboratories,and as a back-up system for large laboratories.

\section{Acknowledgement}

We would like to thank Mrs. H. Hotschek, Mrs. L. Nykiel and Mr. P. Hajdusich (Vienna), Mrs. Müller-Müller (Munich), Mr. A. Codeglimi (Milan), Mrs. C. Hennequin and Mrs. A. Nicolas (Paris) for their dedicated work in carrying out the analysis. Furthermore, we thank Mr. R. Barembruch (Boehringer Mannheim $\mathrm{GmbH}$ ) for the support in the statistical evaluation. 


\section{References}

1. Haeckel, R., Busch, E. W., Jennings, R. D., Kohholm, G. \& Truchaud, A. (1985) ECCLS Document 5, No. 6 (3rd draft).

2. Knedel, M., Haeckel, R., Seidel, D., Thiery, J., Vonderschmitt, D. J., Haenseler, E., Hubbuch, A., Stockmann, W. \& Völkert, E. (1986) J. Clin. Chem. Clin. Biochem. 24, 409-432.

3. Empfehlungen der Deutschen Gesellschaft für Klinische Chemie (1970) J. Clin. Chem. Clin. Biochem. 8, 182-192.

4. Empfehlungen der Deutschen Gesellschaft für Klinische Chemie (1972) J. Clin. Chem. Clin. Biochem. 10, 182-192.

5. Rauscher, E., Bülow, S. v., Neumann, U. \& Schaich, E. (1981) Ber. Österr. Ges. Klin. Chem. 4, 150.

6. Scholer, A. \& Hohenwallner, W. (1984) J. Clin. Chem. Clin. Biochem. 22, 677-684.

7. Szasz, G., Gruber, W. \& Bernt, E. (1976) Clin. Chem. 22, $650-656$

8. Gruber, W. (1978) Clin. Chem. 24, 177-178.

9. Persijn, J. P. \& Van der Slik, W. (1976) J. Clin. Chem. Clin. Biochem. 14, 421-427.
10. Szasz, G. \& Persijn, J. P. (1974) J. Clin. Chem. Clin. Biochem. 12, 228.

11. Wahlefeld, A. W., Herz, G. \& Bernt, E. (1972) Scand. J. Clin. Lab. Invest. 29; Suppl. 126, Abstract 11.12.

12. Seidel, J. Hägele, E. O., Żiegenhorn, J. \& Wahlefeld, A. W. (1983) Clin. Chem. 29, 1075-1080.

13. Bartels, H. (1972) Clin. Chem. Acta 37, 193-197.

14. Wahlefeld, A. W. (1969) Ann. Clin. Biochem. 6, 24.

15. Nägele, U., Hägele, E. O., Sauer, G., Wiedemann, E., Lehmann, P., Wahlefeld, A. W. \& Gruber, W. (1984) J. Clin. Chem. Clin. Biochem. 22, 165-174.

16. Neumann, U. \& Ziegenhorn, J. (1977) XVI. Nordiska kongressen for klinisk kemi och klinisk fysiologi Oulu, Finland.

17. Klose, S. (1981) Boehringer Mannheim GmbH, pers. communication.

18. Broughton, P. M. G., Gowenlock, A. H., McCormack, J. J. \& Neill, D. W. (1984) Ann. Clin. Biochem. 11, 207-218.

19. Passing, H. \& Bablok, W. (1983) J. Clin. Chem. Clin. Biochem. 21, 709-720.

20. Passing, H. \& Bablok, W. (1984) J. Clin. Chem. Clin. Biochem. 22, $431-445$.

Dr. W. Stocköanan

Boehringer Mannheim GmbH

Sandhofer Straße 116

D-6800 Mannheim 31 